\title{
Evaluating the Efficacy of Fertilisers Derived from Human Excreta in Agriculture and Their Perception in Antananarivo, Madagascar
}

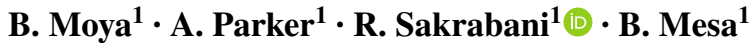

Received: 23 November 2016 / Accepted: 16 October 2017 / Published online: 27 October 2017

(c) The Author(s) 2017. This article is an open access publication

\begin{abstract}
Sustainable food production to achieve food security and increased access to safely managed sanitation are major global challenges. Treating human excreta and producing safe nutrient-rich soil amendments is an effective way of creating an incentive to tackle these two challenges. This research analysed the quality of fertilisers produced from human excreta and evaluated their acceptability within the local market. Antananarivo (Madagascar) was the field site for crop trial and three different fertilisers derived from human excreta were used to grow maize: digestate, compost and vermicompost, each derived from the previous one. The three fertilisers had different characteristics: nutrients were more concentrated in compost $(23 \mathrm{~g} / \mathrm{kg})$ and vermicompost $(11 \mathrm{~g} / \mathrm{kg})$ and mineralisation stages varied between them but did not cause any detrimental effect to crop yield. When compared to chemical fertilisers, the three human excreta derived fertilisers resulted in comparable yield which is encouraging. A series of 81 interviews were also carried out with farmers of the peri-urban area of Antananarivo, which highlighted the importance of characterising the market, identifying users' perceived needs and developing a product responding to these. The majority of local farmers perceived human excreta derived fertilisers as acceptable and gave great importance to their texture and general appearance. In this study, both the field trials and interviews suggest that there is a good potential to produce fertilisers from human excreta, which have a positive effect on crops and can be adopted in the local market.
\end{abstract}

R. Sakrabani

r.sakrabani@cranfield.ac.uk

1 School of Water, Energy and Environment, Cranfield University, Bedford, MK43 0AL, UK
Keywords Human excreta $\cdot$ Fertilisers $\cdot$ Compost . Vermicompost $\cdot$ Digestate $\cdot$ Crops

\section{Introduction}

\section{Food Security Challenges}

Global food security is recognised as one of the major challenges for sustaining 9 billion people on Earth by 2050 . Considering the current rate of population growth it is predicted that the demand for food will double by 2050, putting unprecedented pressures on natural resources [1]. This resonates with the concept of the 'Perfect Storm', introduced by Sir John Beddington in 2009 [2] to illustrate the pressures of increasing demand of food, water and energy worldwide on our finite resources on Earth. This issue is exacerbated by the increasing urbanisation rates worldwide: current food production and consumption patterns have turned cities into nutrient 'sinks'. Food is produced in rural areas, transported and consumed in cities where the nutrients remain, creating an additional demand for artificial fertilisers to replenish lost soil nutrients. In recent years the concept of a circular economy has gained interest and the need for shifting from linear to circular production processes where waste streams become input streams into new processes has been recognised [3]. This is especially true in agriculture where the predicted increase in fertiliser demand is combined with finite mineral nutrient reserves creating an urgent need to close nutrient loops by returning waste nutrients into soil [4, 5].

The issue of soil nutrient depletion will only become more critical in coming years with larger urban populations, which combined with a global rise in fertiliser prices will constitute a major issue to tackle especially in low income countries [6]. There is indeed a gradual nutrient depletion 
of soils in Sub-Saharan Africa (SSA) due to the agricultural practices and lack of fertiliser use in the area [7,8]. Mueller et al. [9] identified that in order for SSA to attain its maximum th eoretically attainable yield for major cereal crops, there is a need for additional nutrient inputs into soil. SSA is indeed the region in the world that currently uses the least fertiliser quantities, about $8 \mathrm{~kg} / \mathrm{ha}$ which is less than one-tenth of the world average [10]. This trend needs to be shifted to increase the agricultural output of the area and allow food production to meet the requirements of an everincreasing population. The term fertiliser covers both inorganic and organic sources and in the latter case the source is also mentioned to indicate its origin.

\section{The Opportunity of Human Excreta Derived Fertilisers}

Over $34 \%$ of the world's population still lacks access to adequate sanitation nowadays with cost implications of over $\$ 260$ billion a year which calls for action and a shift in the conventional approach to sanitation [11]. Non-sewered sanitation is often the norm in most low income countries and especially in informal settlements of rapidly expanding cities; it is estimated that $65-100 \%$ of sanitation access in urban areas in Sub-Saharan Africa is provided through onsite technologies [12]. This type of facility requires emptying and an associated disposal system, which often is not in place in these areas and results in a discharge of the faecal sludge (FS) in the local environment creating a threat to human health. It is therefore essential to put systems in place for the safe handling and transport of FS and provide incentives for its safe disposal through treatments that generate marketable products from human excreta. One type of product that can be produced from human excreta is soil amendments. Once they have reached adulthood, humans do not incorporate nutrients into new body tissue, thus the amount of nutrients consumed and excreted by adult humans is roughly equal [6]. Human excreta therefore constitute a substantial source of nutrients: it is estimated that if excreta of the whole world population were collected, it would constitute $28 \%$ of the current $\mathrm{N}$ (nitrogen), $\mathrm{P}$ (phosphorus) and $\mathrm{K}$ (potassium) consumption worldwide [3].

The opportunity in fertilisers derived from human excreta is recognised but their value is underestimated [13]. Human excreta have a great fertiliser potential; not only do they contain essential plant nutrients such as N, P, K and other micronutrients but it they are also made up of organic matter that improves soil health by increasing its water retaining capacity, reducing erosion and building better structure [14]. The reuse of human excreta as a fertiliser is therefore an attractive solution to both the sanitation crisis and the nutrient depletion of soils in SSA. Sanitation crisis occurs where health conditions decline due to poor practices in managing disposal of faecal matter exacerbated with increasing population $[14,15]$. The conversion of faecal matter into valuable products such as fertilisers also minimises environmental risks linked with pollution incidences if managed properly [16].

Studies to evaluate the fertilising potential of treated sludges have been carried out with materials derived from different substrates, the most common being animal manure as shown in Table 1 . The feasibility of composting and vermicomposting human excreta and obtaining a product safe to use on crops has been demonstrated [6,14-17] but reports of their effect on soil in field trials is limited $[13,18]$.

\section{Challenges in Commercialising Human Excreta Derived Fertilisers in Low Income Countries}

Whilst the positive effects of organic amendments on soil have been proven, compost has often been reported to be hard to market profitably in developing countries. This is often associated with low willingness to pay of customers for waste-derived products due to perception [33]. Producing effective organic soil amendments derived from human excreta therefore does not guarantee their commercial success and if local market conditions are not favourable for organic fertiliser marketing, it is unlikely that a profit will be made from their sale.

For most farmers, the use of fertilisers derived from human excreta would involve a change in their agricultural practices to a certain degree, it would be an innovative adoption which is always perceived as carrying some risk. Smallholder farmers in low income countries most often have very limited capital, preventing them from investing in their farming activities. It is for this reason that they are generally very risk-averse and that it is difficult to change their habits and practices [16].

This is one of the major challenges for commercialising innovative fertiliser products in low income settings. Social capital however can lower the barriers to the adoption of new products and can be a driving factor for innovation among farmers. By facilitating collective work, social capital encourages cooperation and support between farmers as well as lowering costs and therefore overall reduces the risk of adopting innovative practices [34].

\section{The Context in Madagascar}

Madagascar is a country where both access to sanitation and agricultural productivity are current issues. Madagascar remains one of the lowest fertiliser users in Africa with about $4 \mathrm{~kg} / \mathrm{ha}$ of fertiliser applied [35] yet agriculture is a pillar sector of the economy, employing $80 \%$ of the workforce but producing only around one-third of the GDP [36]. The urban population in Madagascar is rapidly increasing with $40 \%$ of the population expected to live in 
Table 1 Summary of crop trials completed with application of anaerobic digestates (AD) or vermicompost derived from excreta (animal and human)

\begin{tabular}{|c|c|c|c|c|}
\hline Type of fertiliser & Crop & Country & Application rate & References \\
\hline Faecal sludge (FS) & Reeds (E. pyramidalis, C. papyrus) & Missing info & Missing info & [19] \\
\hline FS & & Tamale, Ghana & $455 \mathrm{~kg} / \mathrm{ha}$ & {$[20]$} \\
\hline Raw FS & & Ghana & $56 \mathrm{~m}^{3} / \mathrm{ha} \mathrm{FS}$ & [21] \\
\hline $\begin{array}{l}\text { Dewatered FS, MSW compost and co- } \\
\text { compost (FS + MSW) }\end{array}$ & Maize & Ghana & $91,150,210 \mathrm{~kg} \mathrm{~N} / \mathrm{ha}$ & [22] \\
\hline Urine and humanure & Maize & Zimbabwe & & [14] \\
\hline $\begin{array}{l}\text { Vermicompost from septic tank sewage } \\
\text { sludge }\end{array}$ & Habanero peppers & Mexico & 1,2 and $2.5 \mathrm{~kg} / \mathrm{m}^{2}$ & [23] \\
\hline Municipal sewage vermicompost & Tomato & India & $10,2030 \mathrm{t} / \mathrm{ha}$ & [24] \\
\hline $\begin{array}{l}\text { AD from wine distillery wastewater and } \\
\text { organic material }\end{array}$ & Lettuce & Italy & $140 \mathrm{~kg} \mathrm{~N} / \mathrm{ha}$ & {$[25]$} \\
\hline $\begin{array}{l}\text { Pig manure vermicompost (11 different } \\
\text { mixes) }\end{array}$ & Tomato & USA & & {$[26]$} \\
\hline AD from cow dung and chicken droppings & Maize and guinea corn & Nigeria & & [27] \\
\hline Guinea pig manure digestate & Potato and forage & Peru & $50 \mathrm{~kg} \mathrm{~N} / \mathrm{ha}$ & [28] \\
\hline Four different digestates and pig manure & Spring wheat & Sweden & 35,70 and $140 \mathrm{~kg} \mathrm{~N} / \mathrm{ha}$ & [29] \\
\hline $\begin{array}{l}\text { Liquid swine manure, raw and treated } \\
\text { through different processes }\end{array}$ & Maize & Canada & $100 \mathrm{~kg} \mathrm{~N} / \mathrm{ha}$ & {$[30]$} \\
\hline Digestate from cattle slurry and maize mix & Maize & Italy & $340 \mathrm{~kg} \mathrm{~N} / \mathrm{ha}$ & [31] \\
\hline $\begin{array}{l}\text { Digestate, cattle slurry, pig slurry and min- } \\
\text { eral fertiliser }\end{array}$ & $\begin{array}{l}\text { Maize, winter wheat, Italian and } \\
\text { perennial ryegrass }\end{array}$ & Germany & $60,120,180 \mathrm{~kg} \mathrm{~N} / \mathrm{ha}$ for maize & [32] \\
\hline
\end{tabular}

urban areas by 2020 [37]. Peri-urban agriculture plays an essential role in supporting the food requirements of the urban population. There are however great pressures on land in the peri-urban areas of the capital due to the urban expansion. Agricultural activities are gradually being pushed to areas that had not been cultivated before due to their lower soil quality, creating new challenges for making these soils fertile [38]. There are also sanitation issues in Madagascar, only $12 \%$ of the population has access to improved sanitation and $40 \%$ of the population still practises open defecation according to UNICEF statistics from 2015. The situation has only marginally improved over the years with only $8 \%$ more of the population gaining access to sanitation since 1990 [39]. Madagascar and in particular the capital Antananarivo therefore constitute an ideal site for investigating the properties of human excreta derived fertilisers and their commercialisation potential locally. This study aimed to demonstrate the efficacy of three different types of fertilisers derived from human excreta (digestate, compost and vermicompost) compared to inorganic fertilisers and investigate their acceptability amongst farmers in the peri-urban area of Antananarivo. The focus of this study in entirely on the agronomy and valorisation whilst an on-going study is taking place to cover the pathogen and safety aspects of the fertilisers.

\section{Methodology}

\section{Field Trial}

A field trial was carried out in Antananarivo between November 2014 and March 2015 on a $60 \mathrm{~m}^{2}$ plot of land with maize (Zea mays) as a test crop. The field was in the peri-urban area of Antananarivo, in the neighbourhood of Ambohijanahary (Coordinates of the site: $18^{\circ} 49 \times 37.74^{\prime \prime} \mathrm{S}$, $\left.47^{\circ} 29 \times 30.12^{\prime \prime} \mathrm{E}\right)$. The soil in this area according to the World Reference Base (WRB) can be classified as Umbric Gleysol or Ferralsol. The soil texture was loamy sand according to the sand, silt and clay content of the soil, determined by the sieving and sedimentation method (Table 3 ). Five soil samples were collected across the whole length and width of the field before application of soil amendments to test the soil homogeneity.

The organic soil amendments (Table 2) applied on the experimental plots (Fig. 2) were obtained from human excreta derived from a staged treatment process (Fig. 1). Excreta were first collected from Loowatt Ltd dry toilets (equipped with a biodegradable liner and their patented sealing system), which was then anaerobically digested. The resulting digestate was composted with rice straw $(0.45 \mathrm{~kg} \mathrm{straw} / \mathrm{kg}$ digestate) for one month in windrows turned twice every week. Finally, the resulting compost 
Table 2 Comparison of the nutrient content of the different soil amendments applied

\begin{tabular}{llll}
\hline Parameters & Digestate & Compost & Vermicompost \\
\hline $\mathrm{pH}$ & $8.5 \pm 0.05$ & $8.7 \pm 0.14$ & $7 \pm 0.06$ \\
Total N & $877 \pm 57(\mathrm{mg} / \mathrm{L})$ & $23 \pm 3.6(\mathrm{~g} / \mathrm{kg})$ & $11 \pm 0.1(\mathrm{~g} / \mathrm{kg})$ \\
Ammonium N $(\mathrm{mg} / \mathrm{kg})$ & $210 \pm 27$ & $32 \pm 0.9$ \\
Nitrate $(\mathrm{mg} / \mathrm{kg})$ & $7 \pm 2.6$ & $977 \pm 36.2$ \\
Organic C $(\mathrm{g} / \mathrm{kg})$ & $393 \pm 16.8$ & $175 \pm 7.6$ \\
$\mathrm{C} / \mathrm{N}$ ratio & & 17 & 16.6 \\
Total P $(\mathrm{mg} / \mathrm{L})$ & & \\
Extractable P $(\mathrm{mg} / \mathrm{kg})$ & & $21 \pm 0.6$ & $212 \pm 6.3$ \\
Exchangeable K $(\mathrm{g} / \mathrm{kg})$ & $42 \pm 3$ & $26.4 \pm 2.8$ & $5.07 \pm 0.2$ \\
Exchangeable Ca $(\mathrm{mg} / \mathrm{kg})$ & & $349 \pm 122$ & $881 \pm 24.2$ \\
Exchangeable $\mathrm{Mg}(\mathrm{mg} / \mathrm{kg})$ & & $252 \pm 60$ & $946 \pm 17.9$ \\
Exchangeable $\mathrm{Mn}(\mathrm{mg} / \mathrm{kg})$ & & $6.6 \pm 0.45$ & $6.6 \pm 0.28$ \\
Exchangeable $\mathrm{Zn}(\mathrm{mg} / \mathrm{kg})$ & & $3.5 \pm 0.78$ & $0.9 \pm 0.2$ \\
\hline
\end{tabular}

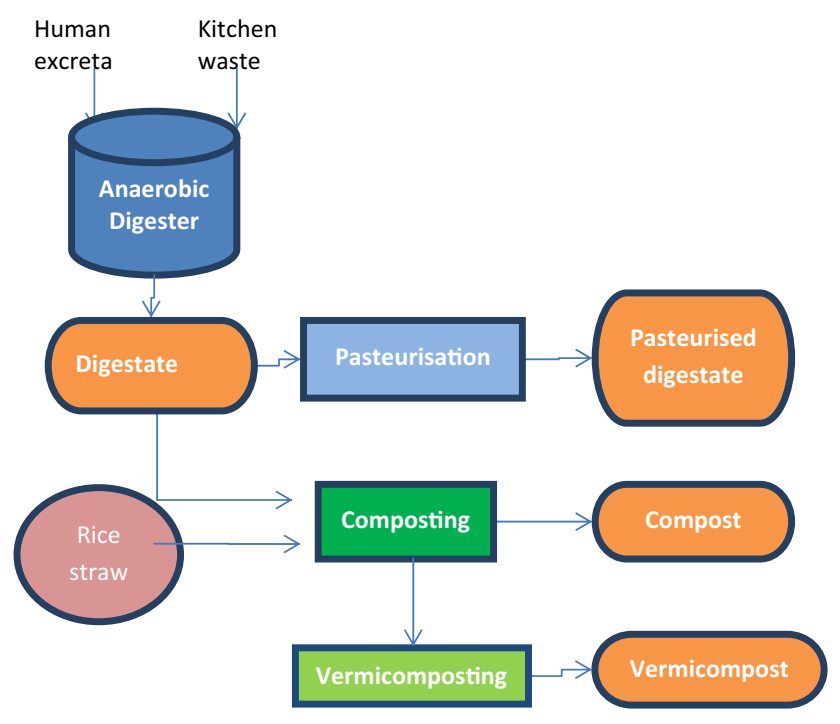

Fig. 1 Fertiliser production process

was vermicomposted at ambient temperature, overall yielding three products with potential fertilising value: anaerobic digestate, compost and vermicompost. These three fertilisers are derived from one another, which allowed an investigation of the evolution of nutrients from one treatment stage to the next. The effect of these organic treatments was compared to that of the chemical fertiliser most commonly used in the area of experimentation: NPK at 11-22-16 ratio.

The effect of four different treatments were compared: digestate (D), compost (C), vermicompost (V), inorganic chemical fertiliser (I) with application rates ranging from 20 to $100 \%$ of total recommended fertiliser application [40] with $20 \%$ increments between successive rates. A randomised complete block design was followed in this experiment: three replicates per treatment were randomly distributed in the field in $0.6 \mathrm{~m}^{2}$ plots with each replicate made up of three maize plants.

$33 \mathrm{~kg} / \mathrm{ha}$ of $\mathrm{N}$ was applied for maize following Malagasy government's guidelines [40, 41] and using the $\mathrm{N}$ content of each fertiliser shown in Table 1 as the basis for calculating fertiliser quantities. The $100 \%$ rate of application for vermicompost, compost and anaerobic digestate were 0.3 , $0.14 \mathrm{~kg} / \mathrm{m}^{2}$ and $2.9 \mathrm{~L} \mathrm{~m}^{2}$ respectively. The field layout is shown in Fig. 2. The total dose of compost, vermicompost and digestate was applied before sowing the seeds. No crop irrigation was necessary since crops were planted during the rainy season, corresponding to an average monthly precipitation of $237 \mathrm{~mm}$ between the months of November and March [42].

The nutrient content of the fertiliser was analysed in July 2014 by a commercial laboratory in Antananarivo, LRI (Laboratoire Radio Isotopes). Standard methods were used for the nutrient analyses: pH determined in $1 \mathrm{M} \mathrm{KCl}$ [43], organic carbon by the wet oxidation method [44], available $\mathrm{N}$ by extraction by $\mathrm{CaCl}_{2}$ followed by thermocolorimety [45], total $\mathrm{N}$ was determined by the Kjeldhal method [46], exchangeable micronutrients ( $\mathrm{K}, \mathrm{Ca}, \mathrm{Mg}, \mathrm{Zn}$ and $\mathrm{Mn}$ ) were extracted by cobalt hexamine followed by spectrophotometric measurement [47], available Phosphorus was determined by extraction using sodium hydrogen carbonate and measured colorimetrically (methylene blue) [48] and total Phosphorus by mineralisation by $\mathrm{HClO}_{4}$ and measured by colorimetry (methylene blue) [49].

Plant parameters were monitored weekly throughout crop growth (plant height, stem thickness and number of leaves). When crop maturity was reached, maize cobs were harvested from each plot and measured and weighed to obtain yield information. Final plant biomass was also recorded for each plot. Data were analysed by factorial ANOVA using the 


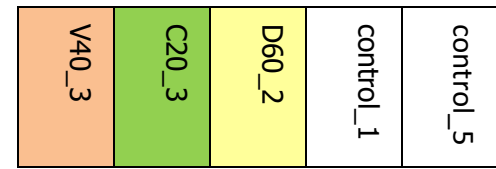

\begin{tabular}{|c|c|c|c|c|}
\hline ১ু & م & ঠ & $\begin{array}{l}\text { ㅁ } \\
\text { ! } \\
\end{array}$ & $\begin{array}{c}\text { ภ } \\
\text { In }\end{array}$ \\
\hline 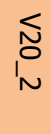 & $\begin{array}{l}\text { 苦 } \\
\text { | } \\
\sim\end{array}$ & $\begin{array}{l}\stackrel{\bullet}{\circ} \\
{ }^{\circ}\end{array}$ & 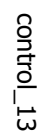 & $\begin{array}{c}\mathfrak{f} \\
\stackrel{0}{o} \\
\omega\end{array}$ \\
\hline
\end{tabular}

Legend:

Fertiliser type application rate (\%)_repetition number

$\mathrm{V}$ : vermicompost

C : compost

D : digestate

I : chemical fertiliser

Scale:

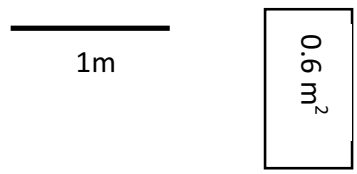

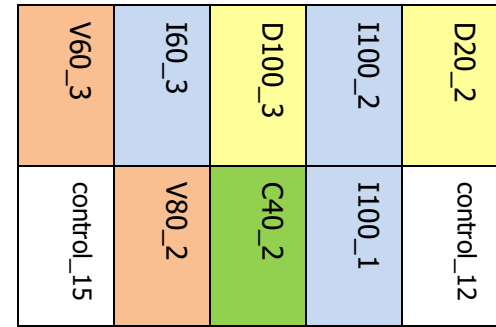
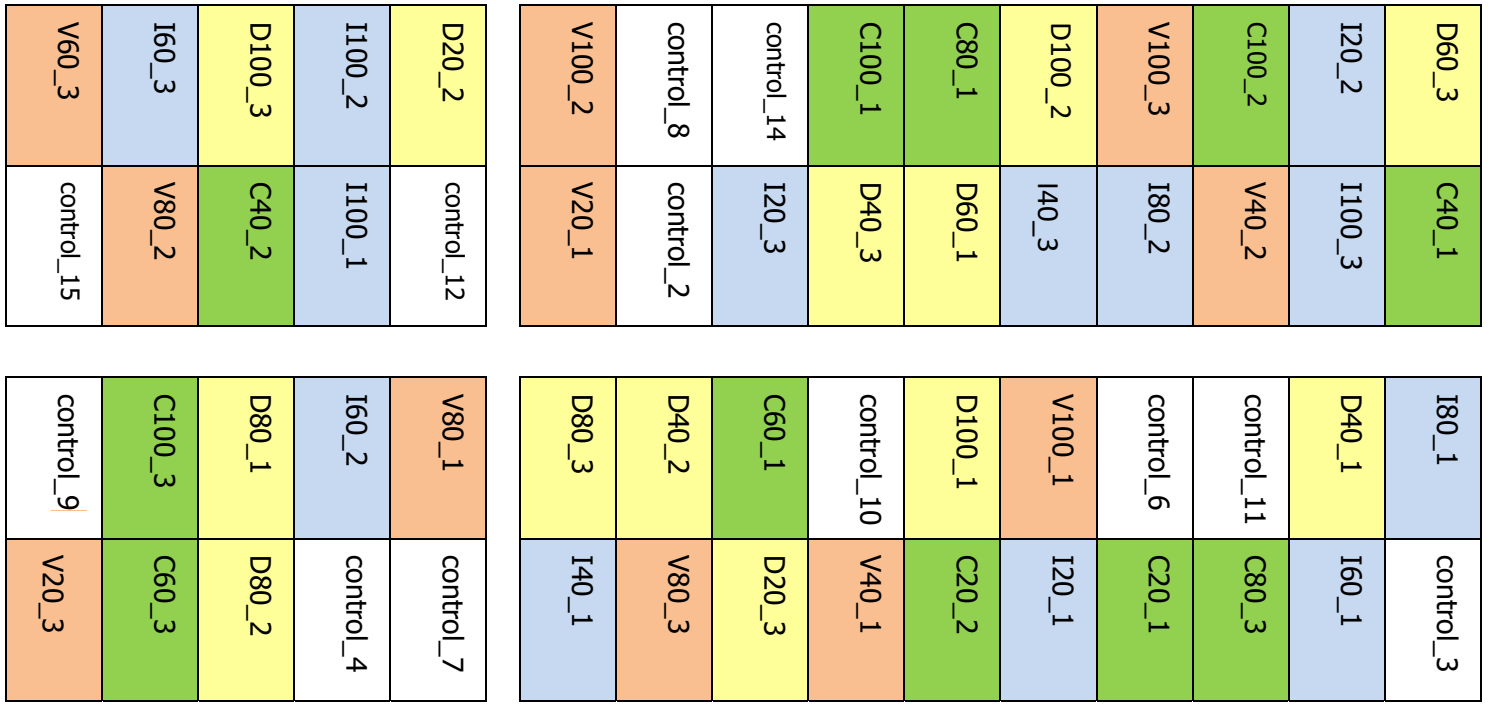

Fig. 2 Maize plots layout

Table 3 Initial soil conditions at pilot site (before applying soil amendments)

\begin{tabular}{ll}
\hline Parameters & Value \\
\hline $\mathrm{pH}$ & 4.89 \\
Total carbon & $1.92 \%$ \\
Organic matter & $3.3 \%$ \\
Clay content & $10 \%$ \\
Silt content & $5 \%$ \\
Sand content & $85 \%$ \\
Ammonium concentration $\left(\mathrm{NH}_{4}\right)$ & $3.68 \pm 0.47$ \\
Nitrate concentration $\left(\mathrm{NO}_{3}\right)$ & $28.54 \pm 3.82$ \\
\hline
\end{tabular}

statistical analysis software Statistica 11 [50], and means compared by a Least Significant Differences (LSD) test with significance determined at $\mathrm{p} \leq 0.05$. There were three replicates for each parameter.

\section{Farmer Interviews}

A series of 81 face to face structured interviews with individual farmers were conducted in the peri-urban area of Antananarivo between January and March 2015. Interviews were carried out in 17 different neighbourhoods within a $1 \mathrm{~h}$ bus journey from the capital's city centre and each interview lasted roughly $1 \mathrm{~h}$. Farmers were found by walking through the fields of each neighbourhood and inviting them to participate in an interview. The central topics of the interview were the farmer's socio-cultural background, their agricultural practices as well as their fertiliser use and their reaction to fertilisers derived from human excreta. To find out the influence of the origin of the fertilisers on the farmers' perception of them, farmers were first presented with the 
fertilisers derived from human excreta without the origin of the fertiliser being disclosed. Once they had given their opinion and stated whether they would be willing to use them, interviewees were then told the fertilisers were partly made from human excreta and they were asked again their opinion about the product.

The interviews were structured questionnaires; answers were recorded on paper during each interview and subsequently transcribed for statistical analysis. The structured nature of the interviews allowed quantitative analysis of the data to produce descriptive statistics.

\section{Results}

\section{Comparison of the Nutrient Content of the Different Fertilisers Applied}

The nutrient concentration of the three types of fertilisers used in this trial differs as can be seen in Table 2, showing the nutrient transformations that occur in each treatment step. Fewer parameters were analysed for the digestate than the compost and vermicompost because of the limited capability of the local laboratory in Antananarivo. The nutrient content of the digestate and compost could not directly be compared because not all the parameters were analysed due to the challenges in dealing with liquid samples such as digestate. The total $\mathrm{N}$ content increased from $0.88 \mathrm{~g} / \mathrm{L}$ in the digestate (approximately equivalent to $0.88 \mathrm{~g} / \mathrm{kg}$ given that the digestate had a density similar to that of water) to $23 \mathrm{~g} / \mathrm{kg}$ in compost, due to the addition of rice straw and the concentration phenomenon that occurs during composting through the degradation of organic carbon compounds [51].
The total $\mathrm{N}$ concentration in the vermicompost was $85 \%$ lower than that in compost, however the $\mathrm{N}$ compound form was different: the overall amount of available $\mathrm{N}$ (ammonium and nitrate concentrations combined) in vermicompost was $1009 \mathrm{mg} / \mathrm{kg}$ compared to only $217 \mathrm{mg} / \mathrm{kg}$ in compost. The available $\mathrm{P}$ concentration was ten times higher in vermicompost than compost; similarly as with $\mathrm{N}$, the digestion process of the worms changed the form in which the $\mathrm{P}$ is present from an organically bound to a soluble and available form.

Project-related time pressures and difficulties in securing trial sites in the peri-urban area of Antananarivo meant that soil quality tests could not be carried out before selecting the experimental site. The soil quality at the trial site is given in Table 3 and was of good quality as a result of regular organic fertiliser applications during previous crop growing seasons; the organic matter content of the soil was as high as that in forests [52] and the $\mathrm{pH}$ was acidic (Table 3), which affected the results of the crop trial.

No clear trends were observed between the yields or the size of cobs harvested from plots treated with different fertilisers applied at different rates as can be seen in Fig. 3. No statistically significant differences $(\mathrm{p}>0.05)$ were observed between the yields obtained with different fertilisers and the different rates applied. Whilst little differences were observed between the different fertilisers applied, it could be noted that the human excreta derived fertilisers did not have a negative effect on soil or crop growth and that in this experiment the effect of the excreta derived and chemical fertilisers was comparable.

In this study, currently there is limited information about the pathogens as further work is in progress to quantify it. However, the preliminary data show that the risk from $E$.

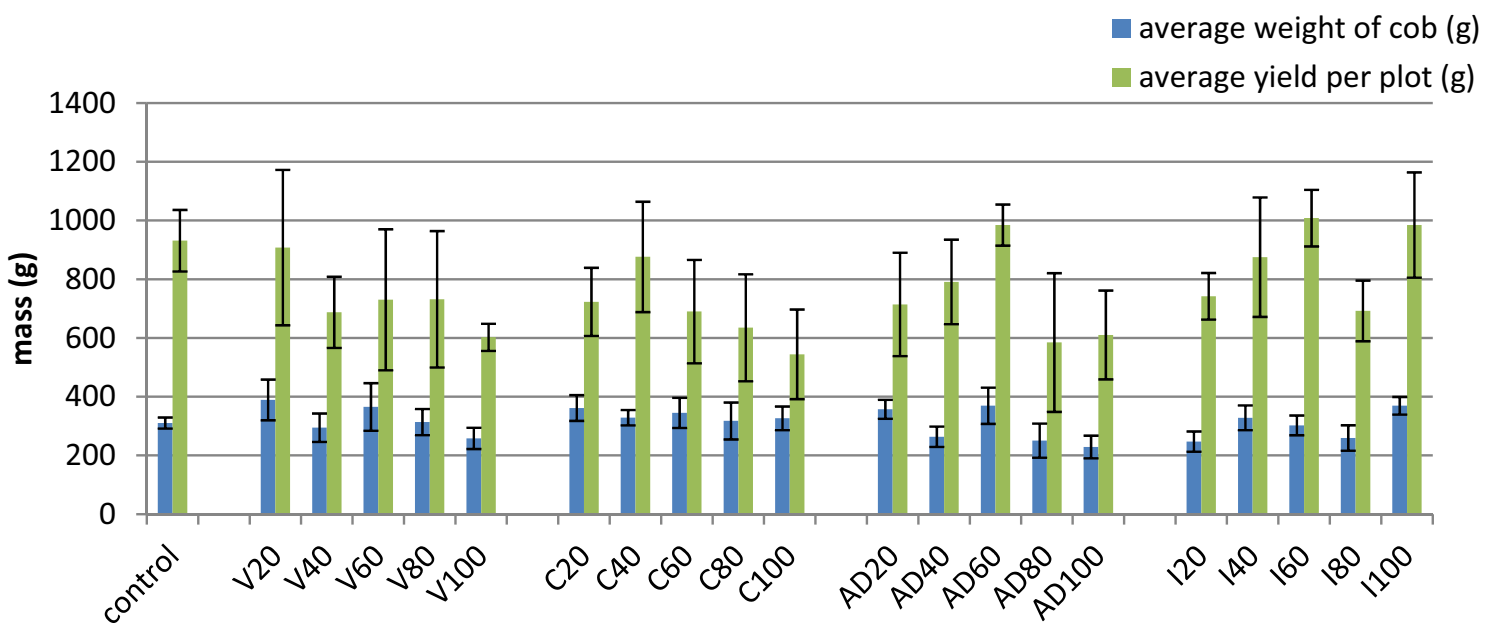

Fertiliser treatment applied

Fig. 3 Maize yield from experimental plots: mean cob weight and yield per plot (bars indicate standard errors; $V$ vermicompost; $C$ compost; $A D$ anaerobic digestate; $I$ inorganic fertiliser; figures $20,40,60,80,100$ indicate $\%$ of the total fertiliser application) 
coli is below the risk levels outlined by the WHO guidelines for the safe use of wastewater, excreta and greywater [53].

\section{Interviews with Farmers of the Peri-Urban Area of Antananarivo}

The main findings from the interviews are summarised in Table 4. One of the aims of the interviews was to understand the social capital of farmers of the peri-urban area of Antananarivo in order to identify suitable channels to reach potential fertiliser customers. It was however found that only $28 \%$ of interview respondents were members of local groups or associations, none of these were related to farming. It was also found that farming in the peri-urban area was mostly based on traditional practices since only $9 \%$ of respondents had received agriculture-related training and hence their knowledge of soil health is based on traditions more than understanding nutrient content of soil or plant needs. $93 \%$ of farmers use fertilisers on their land with many of them using a mix of both organic and chemical fertilisers. Farmers in the peri-urban area are subsistence farmers with small plots of land and a very low purchase power; $51 \%$ wanted to change the fertiliser they used and out of those, $39 \%$ stated that a lack of financial means was their main barrier to change.

After being asked about their background and farming habits and experiences, interview respondents were pre- use them on their field. They were then told that the fertilisers were made from human excreta and only $16 \%$ changed their mind once they knew. None of them had ever heard of vermicompost before it was shown to them and it was not perceived to have a higher value than other organic soil amendments. Farmers were unaware of the process of vermicomposting, which highlighted the low farming-related education level of farmers of the peri-urban area. About half of the interviewees however stated they would prefer using vermicompost to compost on their fields, principally because of its appearance and structure rather than its added beneficial properties compared to compost.

No farmers had ever used liquid fertilisers previously, implying that liquid digestate as a fertiliser would be unlikely to be adopted in the area by smallholder farmers. These two examples highlighted the importance of product structure, presentation and perceived ease of use for farmers when adopting new products.

\section{Discussion}

From the differences in nutrient concentration observed between the excreta derived fertilisers, it was anticipated that there would be differences in the effect on plants when applied to soil. The initial soil quality of the trial site was
Table 4 Farmer interview responses

\begin{tabular}{ll}
\hline Parameter & $\begin{array}{l}\text { Percent- } \\
\text { age of } \\
\text { positive } \\
\text { response }\end{array}$ \\
\hline Men & $78 \%$ \\
Women & $22 \%$ \\
Any farming related training received & $9 \%$ \\
Community involvement, member of any community group & $27 \%$ \\
Have another occupation aside from farming & $51 \%$ \\
Member of a farmers' group & $4 \%$ \\
Own the land they grow crops on & $46 \%$ \\
Subsistence farming & $81 \%$ \\
Sell produce & $77 \%$ \\
Fertiliser use & $93 \%$ \\
$\bullet$ Organic fertiliser & $81 \%$ \\
$\bullet$ Chemical fertiliser & $47 \%$ \\
Reaction to human excreta derived fertilisers & $0 \%$ \\
Willing to use Loowatt's fertilisers after simple visual inspection & \\
Not willing to use the fertilisers any more when told they originate from human excreta & $16 \%$ \\
Prefer vermicompost over compost & $59 \%$ \\
\hline
\end{tabular}

sented with human excreta derived fertilisers without being given any information on their origin; $88 \%$ were willing to very high as a result of regular manure applications in previous years, reducing the need for nutrient additions to the soil 
for healthy crop growth. This reduced the probability of crop response to the fertilisers applied and hence also reduced the likelihood of obtaining statistically relevant differences between experimental plots. The rainfall during the rainy season of 2015 in Madagascar was also particularly high, due to two tropical storms, Chedza and Fundi, which caused severe flooding in the capital [54]. This high rainfall also affected the crops and soil; it is likely that higher nutrient run off took place with rain infiltration, which could be another factor in the reduced crop response to the different fertiliser quantities and types applied.

The evaluation of quality here is based on Soil Quality Indicators as detailed in the UK Environment Agency publication in 2006 [55]. Whilst this is not directly applicable to Madagascar, it provides some ball park figures for soil organic carbon value in arable which ranges between 2-7.6\% (clay soil) and 1-5.6\% (sandy loam). In Table 3 the total carbon value is $1.92 \%$ and based on the soil texture it falls within the good soil quality range for sandy loam.

The nutrient content of composts and vermicomposts has been shown to be highly dependent on the raw materials used to produce it [56,57]; it is therefore difficult to directly compare them unless they originate from the same material. In this experiment however the vermicompost was derived from the same compost used in the crop trial so the nutrient transformation through the vermicomposting process could be traced. The digesting action of the worms had a significant effect on the macro and micronutrient content of the final product; notable differences were observed between the nutrient concentration of compost and vermicompost. Vermicomposting has been shown to accelerate the process of nutrient mineralization and as a result nutrients in vermicomposts are present in more plant-available forms [58]. The concentration of organic carbon in vermicompost was half of that in compost, which is characteristic of vermicomposting, which accelerates $\mathrm{C}$ mineralization [59]. Vermicomposting also had a notable effect on the concentration of secondary micronutrients. The vermicomposting process more than doubled the concentration of Calcium and the concentration of Magnesium was more than three times higher in vermicompost than in compost. The Zinc concentration decreased during the vermicomposting process by more than one-third; this is because the worms bioaccumulate metals [60].

The concentration of total $\mathrm{N}$ was significantly reduced during the vermicomposting process; the final concentration of total $\mathrm{N}$ in vermicompost was less than a quarter than that in compost. This effect has been observed with vermicomposts obtained from different sources; it is most likely due to ammonia losses in the initial stages of the process and is strongly related to the carbon to nitrogen ratio $(\mathrm{C} / \mathrm{N})$ of the initial feedstock $[17,61,62]$. The concentration of organic carbon in compost was almost double to that in vermicompost, which originated from the rice straw added to the digestate for composting. Lower organic carbon in vermicompost could be related to it being assimilated by the worms and partly released as carbon dioxide through respiration thus lowering the carbon concentration in the vermicompost casts. This is in agreement with experimental results reported by Yadav et al. [17] and Orozco et al. [58]. However, the primary nutrients $\mathrm{N}$ and $\mathrm{P}$ were present in soluble and mineralised forms in vermicompost, making them more readily available to plants and making it a faster acting amendment than compost despite the relative lower nutrient concentrations. The ammonium and nitrate concentrations were significantly different between compost and vermicompost. The ammonium concentration in compost was almost seven times higher than in vermicompost and the nitrate concentration in vermicompost was 100 times higher in vermicompost than compost. This suggests that vermicomposting process enables nitrification to take place through the worms' activity digesting organic matter and producing casts, which are more easily consumed by the microorganisms that assist the mineralisation process of producing nitrate. The decrease in $\mathrm{pH}$ as a result of vermicomposting is another factor showing that a nitrification process occurred between the compost to vermicompost stage since protons are released in that reaction, increasing the acidity of the vermicompost.

Nutrient use efficiency (NUE) is a parameter used to evaluate the effectiveness of fertilisers by relating to the crop yield obtained and the fertiliser rates applied according to Eq. (1). When comparing the nutrient use efficiency between plots in Fig. 4, no clear trend was observed, in accordance with the observations made with the yields per plot. Due to the already high initial $\mathrm{N}$ concentration in soil, adding different fractions of $\mathrm{N}$ to the plots did not have a significant impact on the yield obtained. The amount of $\mathrm{N}$ added was one order of magnitude smaller than the concentration of available $\mathrm{N}$ already present in the soil, there was therefore no visible effect of the fertiliser application rates on yields. The highest NUE was obtained with $60 \%$ application of chemical fertiliser and the lowest with $100 \%$ application rate of compost. Higher application rates (80 and 100\%) of vermicompost, compost and chemical fertiliser led to a lower NUE than the lowest application rates. This observation is in accordance with the fact that no significant differences in yield were observed between plots: the lowest and highest fertiliser application rates achieved similar results and hence the lower application rates resulted in a higher efficiency in terms of yield per amount of fertiliser applied.

$\mathrm{NUE}=\frac{\text { Maize yield per plot }}{\text { Nitrogen applied per plot }}$

The NUE trends showed that the highest nutrient efficiencies were achieved at the lower fertiliser application rates (20, 40 or $60 \%$ depending on the treatment), reflecting the 


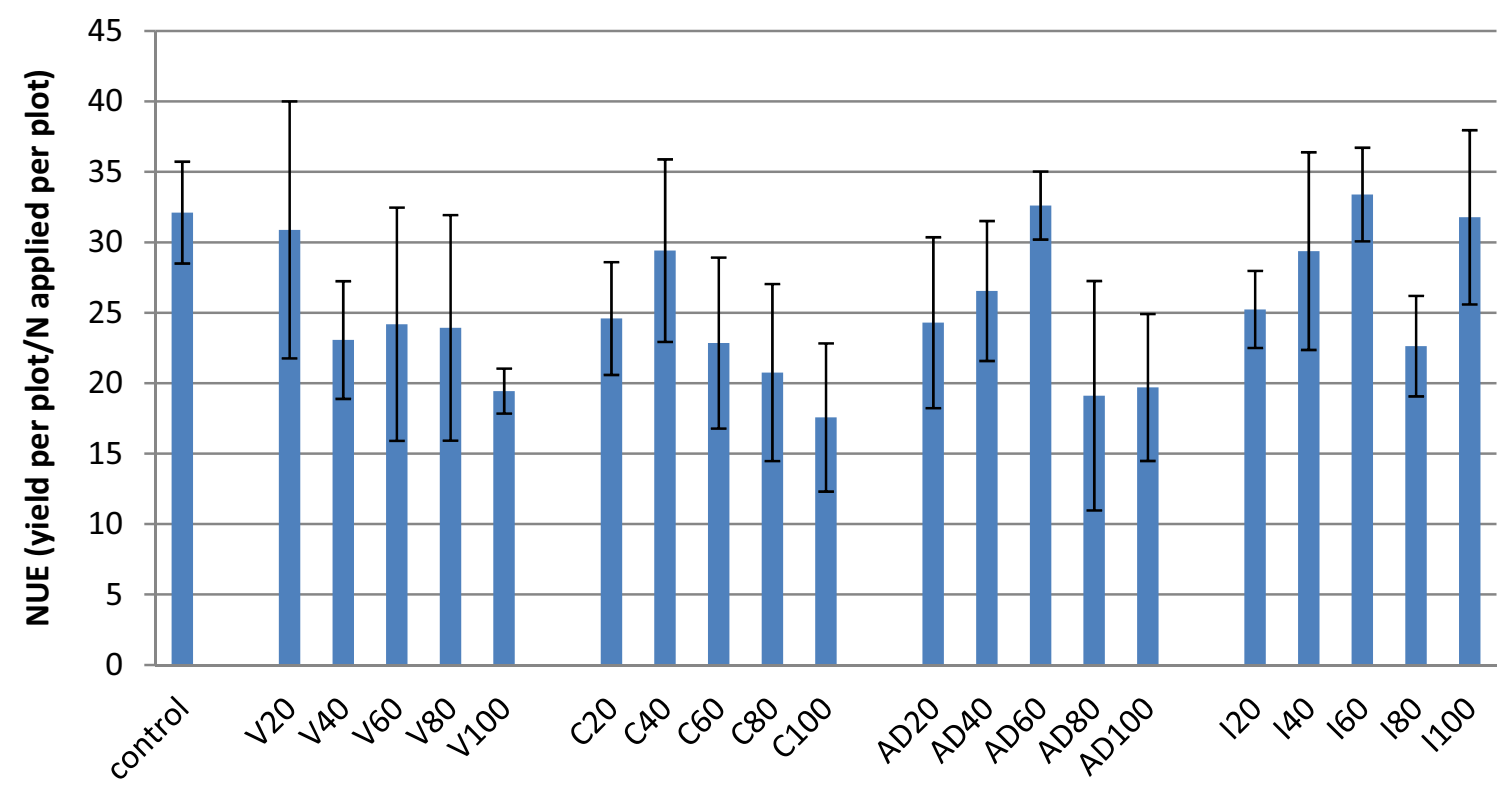

Treatment

Fig. 4 Nutrient use efficiency (NUE) calculated using the mean maize yield per plot (bars indicate standard errors); $V$ vermicompost; $C$ compost; $A D$ anaerobic digestate; $I$ inorganic fertiliser; figures 20,40,60, 80, 100 indicate $\%$ of the total fertiliser application

initial good soil health in the field, which did not require additional N. Low NUE at high rates showed that higher fertiliser applications yielded no added benefits and lower application rates were more efficient in terms of nutrients.

Aside from the agronomic value of fertilisers derived from human excreta, their commercial value also needed to be considered in order to produce a product viable in the local market. The farmer interviews in the peri-urban area helped explore this issue and provided a picture of the local potential customers and their perceived needs. The main point that came out from the interviews is that farmers of the peri-urban area of Antananarivo were not a united or organised collective with little formal agronomical knowledge. The vast majority of farmers in the peri-urban area of Antananarivo had received no formal agronomy related training and their practices were based on local traditional knowledge and know-how passed down through generations. This is a common trend observed in SSA for smallholders, which limits their access to fertilisers and prevents higher crop yields to be achieved [63]. No farmer associations or groups exist in the peri-urban area of the capital, indicating a low social capital at present. Heemskerk and Wennink [64] recognised the importance of existing social capital for introducing innovation for agricultural development in SSA: cases where farmers' social capital was used for shaping and introducing agricultural extension programs were more successful than those where programs were implemented in a top-down approach. Sanginga et al. [65] also highlighted the importance of building social capital in farmer groups to achieve successful results in extension programs. Training is an essential part of introducing a change in farming practices but experience has shown that training alone rarely gives rise to long term adoption of technologies [64]. It is in cases where social capital was used and increased alongside training where uptake of new technologies tends to be higher. At present farmers of the peri-urban area of Antananarivo do not have a common voice, they are not interconnected nor do they have access to knowledge-sharing or trainings, limiting the possibilities for introducing and disseminating innovative practices or products.

In the peri-urban area it was also common for the farmers to have another source of income, $51 \%$ of farmers interviewed had another occupation aside from farming, which implied that the time and attention they dedicated to their fields was limited. Half of the respondents stated finding out about new products through TV or radio adverts, highlighting a lack of connectivity between farmers. The lack of farmers' networks would make it more difficult to target them as a group or implement changes in their agricultural practices.

The positive attitude of farmers towards fertilisers derived from human excreta however indicated that there were little prejudices against human excreta derived products, suggesting that there is no local stigma against FS reuse, which was observed in other contexts [21]. It is however difficult to make a definite statement about the local acceptability of fertilisers derived from Human excreta because of potential interviewer-related bias. In market research and customer 
satisfaction interviews it is common for a 'courtesy bias' to occur: respondents give the answers they think the interviewer is expecting and not their true opinion so as to not cause offence $[66,67]$. According to the interview responses, potential barriers to the use of fertilisers derived from human excreta would not come from a moral prejudice but would rather be related to low purchase power or lack of awareness about new products. The majority of farmers however stated they would not tell their customers about the origin of the fertilisers, showing that there is a fear of stigma of using faecal matter of human origin to produce the fertilisers.

Farmers in the peri-urban area were accustomed to using organic fertilisers but did not buy them in shops, rather bartered them or bought them locally from other farmers. When farmers buy fertilisers they expect them to have similar effects to chemical fertilisers, which is difficult to achieve with organic fertilisers. These characteristics constitute challenges for marketing fertilisers derived from human excreta to local farmers of the peri-urban area of Antananarivo, they do not constitute the ideal customer group for the marketing of a new fertiliser Given the low purchase power of small scale farmers, their farming methods being based on traditional practices and the lack of networking structures within the peri-urban area, farmers of the peri-urban area are unlikely to be the best initial customers for these fertilisers.

\section{Conclusion}

Notable nutrient concentration differences were observed between digestate, compost and vermicompost derived from human excreta. A nutrient evolution was observed through the treatment chain of human excreta: the composting process concentrated the nutrients present in digestate and vermicomposting modified the form in which nutrients (such as nitrates, phosphates Calcium and Magnesium) were present making them more easily available to crops. The quality of the carbon source, which is substrate for the soil microorganisms, was different in compost and vermicompost and influenced the mineralisation and availability of nutrients to crops. The field study showed that human excreta derived fertilisers did not have a detrimental effect on maize. Further field studies on soils with different properties should be carried out to further characterise the effect of the different human excreta derived fertilisers on soil and crops.

Interviews with local farmers of the peri-urban area of Antananarivo highlighted the importance of developing fertiliser products appropriate for the local market targeted. From the interview results it was clear that adoption of liquid digestate as a fertiliser by smallholder farmers would be more challenging than that of a fertiliser in solid form, which farmers are most used to in the peri-urban area. The importance of fertiliser texture was also highlighted by a majority of farmers stating a preference for vermicompost over compost because of its dry and grainy texture, perceived as easier to handle and apply. These findings suggest that if new practices such as the use of fertilisers derived from human excreta are to be adopted by local farmers, there is a need to provide training to increase farmers' understanding of soil health management and fertiliser use. The interviews highlighted the importance of understanding the local market's needs and expectations for successfully commercialising human excreta derived fertilisers as well as adapting product features to potential customer's perceived needs.

Acknowledgements The authors would like to acknowledge the financial support provided by Loowatt Ltd and EPSRC Doctoral Training Account provided through Cranfield University for this research. We are grateful to Loowatt Ltd for providing the human waste derived fertilisers used in this experiment and for the Laboratoire Radio Isotopes (LRI) of Antananarivo, Madagascar, for the soil analyses carried out for this experiment.

Open Access This article is distributed under the terms of the Creative Commons Attribution 4.0 International License (http://creativecommons.org/licenses/by/4.0/), which permits unrestricted use, distribution, and reproduction in any medium, provided you give appropriate credit to the original author(s) and the source, provide a link to the Creative Commons license, and indicate if changes were made.

\section{References}

1. Tilman, D., Balzer, C., Hill, J., Befort, B.L.: Global food demand and the sustainable intensification of agriculture. PNAS. 108, 20260-20264 (2011). doi:10.1073/pnas.1116437108

2. Beddington, J.: Food, energy, water and the climate: a perfect storm of global events? (2009)

3. Ellen MacArthur Foundation: Towards the circular economy: opportunities for the consumer goods sector. Ellen MacArthur Foundation, Cowes (2013)

4. Cordell, D., Drangert, J.-O., White, S.: The story of phosphorus: global food security and food for thought. Glob. Environ. Chang. 19, 292-305 (2009). doi:10.1016/j.gloenvcha.2008.10.009

5. Drangert, J.O.: Urine blindness and the use of nutrients from human excreta in urban agriculture. GeoJ. 45, 201-208 (1998). doi:10.1023/A:1006968110875

6. Bracken, P., Münch, E.V., Panesar, A.R.: Tackling the urban waste and food crises simultaneously and sustainably: examples from the Philippines and Burkina Faso. In: 34th WEDC International Conference, Addis Ababa, Ethiopia. pp. 1-8 (2009)

7. Cofie, O., Kone, D., Rothenberger, S., Moser, D., Zubruegg, C.: Co-composting of faecal sludge and organic solid waste for agriculture: process dynamics. Water Res. 43, 4665-4675 (2009). doi:10.1016/j.watres.2009.07.021

8. Wanzala, M., Groot, R.: Fertiliser market development in SubSaharan Africa. In: Proceedings of the International Fertiliser Society Conference in Windsor, UK (2013)

9. Mueller, N.D., Gerber, J.S., Johnston, M., Ray, D.K., Ramankutty, N., Foley, J.A.: Closing yield gaps through nutrient and water management. Nature 490, 254-257 (2012)

10. Chauvin, N.D., Mulangu, F., Porto, G.: Food production and consumption trends in sub-Saharan Africa: prospects for the transformation of the agricultural sector (2012) 
11. WHO: Global costs and benefits of drinking-water supply and sanitation interventions to reach the MDG target and universal coverage. WHO, Geneva (2012)

12. Strauss, M., Larmie, S. a., Helnss, U., Montangero, A.: Treating faecal sludges in ponds. Water Sci. Technol. 42, 283-290 (2000)

13. Heinonen-Tanski, H., van Wijk-Sijbesma, C.: Human excreta for plant production. Bioresour. Technol. 96, 403-411 (2005). doi:10.1016/j.biortech.2003.10.036

14. Guzha, E., Nhapi, I., Rockstrom, J.: An assessment of the effect of human faeces and urine on maize production and water productivity. Phys. Chem. Earth A/B/C. 30, 840-845 (2005). doi:10.1016/j. pce.2005.08.028

15. Koné, D., Cofie, O., Nelson, K.: Low-cost options for pathogen reduction and nutrient recovery from faecal sludge. In: Drechsel, P., Scott, C.A., Raschid-Sally, L., Redwood, M., Bahri, A. (eds.) Wastewater irrigation and health: assessing and mitigating risk in low-income countries. Eart, London (2009)

16. Graf, J., Kayser, O., Klarsfield, L., Bonsey, R., Brossard, S.: Smallholder farmers and business, 15 pioneering collaborations for improved productivity and sustainability (2015)

17. Yadav, K.D., Tare, V., Ahammed, M.M.: Vermicomposting of source-separated human faeces for nutrient recycling. Waste Manag. 30, 50-56 (2010). doi:10.1016/j.wasman.2009.09.034

18. Kramer, S., Preneta, N., Kilbride, A.: Thermophilic composting of human wastes in uncertain urban environments: a case study from Haiti. In 36th WEDC International Conference, vol. 2011, pp. 1-6 (2013)

19. Kengne, I.M., Akoa, A., Soh, E.K., Tsama, V., Ngoutane, M.M., Dodane, P.H., Koné, D.: Effects of faecal sludge application on growth characteristics and chemical composition of Echinochloa pyramidalis (Lam.) Hitch. and Chase and Cyperus papyrus L. Ecol. Eng. 34, 233-242 (2008). doi:10.1016/j. ecoleng.2008.08.007

20. Asare, I., Kranjac-berisavljevic, G., Kofie, O.: Faecal sludge application for agriculture in Tamale. Urban Agriculture Magazine, pp. 32-33 (1998)

21. Cofie, O.O., Kranjac-Berisavljevic, G., Drechsel, P.: The use of human waste for peri-urban agriculture in Northern Ghana. Renew. Agric. Food Syst. 20, 73-80 (2005). doi:10.1079/ RAF200491

22. Adamtey, N., Cofie, O., Ofosu-Budu, K.G., Ofosu-Anim, J., Laryea, K.B., Forster, D.: Effect of N-enriched co-compost on transpiration efficiency and water-use efficiency of maize (Zea mays L.) under controlled irrigation. Agric. Water Manag. 97, 995-1005 (2010). doi:10.1016/j.agwat.2010.02.004

23. Rodríguez-Canché, L.G., Cardoso-Vigueros, L., Carvajal-León, J., Dzib, S.D.L.C.P.: Production of habanero pepper seedlings with vermicompost generated from sewage sludge. Compost Sci. Utilization 18(1), 42-46 (2010). doi:10.1080/10656 57X.2010.10736932

24. Begum, A.: Evaluation of municipal sewage sludge vermicompost on two cultivars of tomato (Lycopersicon esculentum) plants. Int. J. ChemTech Res. 3(3), 1184-1188 (2011)

25. Montemurro, F., Ferri, D., Tittarelli, F., Canali, S., Vitti, C.: Anaerobic digestate and on-farm compost application: Effects on lettuce (Lactuca sativa L.) crop production and soil properties. Compost Sci. Utilization 18(3), 184-193 (2010). doi:10.1080/10 65657X.2010.10736954

26. Atiyeh, R.M., Arancon, N., Edwards, C., Metzger, J.: Influence of earthworm-processed pig manure on the growth and yield of greenhouse tomatoes. Bioresour. Technol. 75(3), 175-180 (2000). doi:10.1016/S0960-8524(00)00064-X

27. Alfa, M.I., Adie, D.B., Igboro, S.B., Oranusi, U.S., Dahunsi, S.O., Akali, D.M.: Assessment of biofertilizer quality and health implications of anaerobic digestion effluent of cow dung and chicken droppings. Renew. Energy 63, 681-686 (2014). doi:10.1016/j. renene.2013.09.049

28. Garfí, M., Gelman, P., Comas, J., Carrasco, W., Ferrer, I.: Agricultural reuse of the digestate from low-cost tubular digesters in rural Andean communities. Waste Manag. 31, 2584-2589 (2011). doi:10.1016/j.wasman.2011.08.007

29. Abubaker, J., Risberg, K., Pell, M.: Biogas residues as fertilisers - Effects on wheat growth and soil microbial activities. Appl. Energy 99, 126-134 (2012). doi:10.1016/j.apenergy.2012.04.050

30. Chantigny, M.H., Angers, D.A., Bélanger, G., Rochette, P., Eriksen-Hamel, N., Bittman, S., Buckley, K., Massé, D., Gasser, M.O.: Yield and nutrient export of grain corn fertilized with raw and treated liquid swine manure. Agron. J. 100, 1303-1309 (2008). doi:10.2134/agronj2007.0361

31. Cavalli, D., Cabassi, G., Borrelli, L., Geromel, G., Bechini, L., Degano, L., Marino Gallina, P.: Nitrogen fertilizer replacement value of undigested liquid cattle manure and digestates. Eur. J. Agron. 73, 34-41 (2016). doi:10.1016/j.eja.2015.10.007

32. Sieling, K., Herrmann, A., Wienforth, B., Taube, F., Ohl, S., Hartung, E., Kage, H.: Biogas cropping systems: Short term response of yield performance and $\mathrm{N}$ use efficiency to biogas residue application. Eur. J. Agron. 47, 44-54 (2013). doi:10.1016/j. eja.2013.01.002

33. Danso, G., Fialor, S.C., Drechsel, P.: Farmers' perception and willingness to pay for urban waste compost in Ghana. In: Almorza, D., Brebbie, C.A., Sales, D., Popov, V. (eds.) Waste management and the environment, pp. 231-241. WIT Press, Southampton (2002)

34. Pretty, J.: Social capital and connectedness: issues and implications for agriculture, rural development and natural resource management in ACP countries (2003)

35. NEPAD-CAADP: The Abuja declaration on fertilizers for an African Green Revolution: status of implementation at regional and national levels (2015)

36. Koplan, S., Okun, C.D.T., Bragg, L.M., Miller, M.E., Hillman, J.A., Devaney, D.M.: US trade and investment with Sub-Saharan Africa, third annual report (Publication 3552). United States International Trade Commission, Washington (2002)

37. Godinot, X.: Le defi urbain a madagascar quand la misère chasse la pauvreté (2010)

38. Dienor, M.N., Aubry, C., Rabeharisoa, L.: Stratégies de construction de la fertilité des terres par les agriculteurs dans les systèmes maraîchers périurbains d'Antananarivo (Madagascar). Cah. Agric. 20, 280-293 (2011)

39. WHO/UNICEF: 25 years progress on sanitation and drinking water: 2015 update and MDG assessment. UNICEF World Health Organization, New York, NY, p. 4 (2015)

40. Maep, Fao, Psdr: Fiches techniques de base destinées aux techniciens agricoles. Maep, Fao, Psdr, Mais

41. Husson, O., Charpentier, H., Razanamparany, C., Moussa, N., Michellon, R., Naudin, K., Razafintsalama, H., Rakotoarinivo, C., Rakotondramanana, Enjalric, F., Séguy, L.: Maïs ou sorgho associé à une légumineuse alimentaire volubile (Dolique, Niébé ou Vigna umbellata). Man. Prat. du semis direct à Madagascar. V(III), 20 (2010)

42. WMO: Climatological information of Antananarivo, Madagascar, http://worldweather.wmo.int/en/city.html?201605141803\&c ityId $=7$

43. ISO10390:2005: Soil quality: determination of $\mathrm{pH}$ (2005)

44. ISO14235:1998: Soil quality: determination of organic carbon by sulfochromic oxidation (1998)

45. ISO14255:1998: Soil quality: determination of nitrate nitrogen, ammonium nitrogen and total soluble nitrogen in air-dry soils using calcium chloride solution as extractant (1998)

46. ISO11261:1995: Soil quality: determination of total nitrogenmodified Kjeldahl method (1995) 
47. ISO11047:1998: Soil quality: determination of cadmium, chromium, cobalt, copper, lead, manganese, nickel and zinc-flame and electrothermal atomic absorption spectrometric methods (1998)

48. ISO11263:1994: Soil quality: determination of phosphorusspectrometric determination of phosphorus soluble in sodium hydrogen carbonate solution (1994)

49. ISO14869-1:2001: Soil quality: dissolution for the determination of total element content-part 1: dissolution with hydrofluoric and perchloric acids (2001)

50. STATISTICA, v. 11, StatSoft Inc, Tulsa, OK, USA. Available from: http://www.statsoft.com (2011)

51. Bernal, M.P., Paredes, C., Sánchez-Monedero, M. a., Cegarra, J.: Maturity and stability parameters of composts prepared with a wide range of organic wastes. Bioresour. Technol. 63, 91-99 (1998). doi:10.1016/S0960-8524(97)00084-9

52. Foth, H.D.: Fundamentals of soil science. Wiley, New York (1991)

53. WHO: WHO guidelines for the safe use of wastewater, excreta and greywater. Policy Regulat. Aspects 1, 114 (2006)

54. IFRC: Emergency plan of action (EPoA) Madagascar: cyclone Chedza (2015)

55. Merrington, G., Fishwick, S., Barraclough, D., Morris, J., Preedy, N., Boucard, T., Reeve, M., Smith, P., Fang, C.: The development and use of soil quality indicators for assessing the role of soil in environmental interactions. https://www.gov.uk/government/ uploads/system/uploads/attachment_data/file/290729/scho0306bkiq-e-e.pdf

56. Yan, Y.W., Azwady, a a N., Shamsuddin, Z.H., Muskhazli, M., Aziz, S. a, Teng, S.K.: Comparison of plant nutrient contents in vermicompost from selected plant residues. Afr. J. Biotechnol. 12, 2207-2214 (2013). doi:10.5897/AJB11.3164

57. Campitelli, P., Ceppi, S.: Chemical, physical and biological compost and vermicompost characterization: a chemometric study. Chemom. Intell. Lab. Syst. 90, 64-71 (2008). doi:10.1016/j. chemolab.2007.08.001

58. Orozco, F.H., Cegarra, J., Trujillo, L.M., Roig, A.: Vermicomposting of coffee pulp using the earthworm Eisenia fetida: effects on C and $\mathrm{N}$ contents and the availability of nutrients. Biol. Fertil. Soils. 22, 162-166 (1996). doi:10.1007/BF00384449
59. Aira, M., Domínguez, J.: Optimizing vermicomposting of animal wastes: effects of rate of manure application on carbon loss and microbial stabilization. J. Environ. Manage. 88, 1525-1529 (2008). doi:10.1016/j.jenvman.2007.07.030

60. Suthar, S., Singh, S.: Bioconcentrations of metals (Fe, $\mathrm{Cu}, \mathrm{Zn}$, $\mathrm{Pb}$ ) in earthworms (Eisenia fetida), inoculated in municipal sewage sludge: do earthworms pose a possible risk of terrestrial food chain contamination? Environ. Toxicol. 24, 25-32 (2009). doi:10.1002/tox

61. Benitez, E., Nogales, R., Elvira, C., Masciandaro, G., Ceccanti, B.: Enzyme activities as indicators of the stabilization of sewage sludges composting with Eisenia foetida. Bioresour. Technol. 67, 297-303 (1999). doi:10.1016/S0960-8524(98)00117-5

62. Sánchez-Monedero, M. a., Mondini, C., De Nobili, M., Leita, L., Roig, a.: Land application of biosolids. Soil response to different stabilization degree of the treated organic matter. Waste Manag. 24, 325-332 (2004). doi:10.1016/j.wasman.2003.08.006

63. Njoroge, R., Birech, R., Arusey, C., Korir, M., Mutisya, C., Scholz, R.W.: Transdisciplinary processes of developing, applying, and evaluating a method for improving smallholder farmers' access to (phosphorus) fertilizers: the SMAP method. Sustain. Sci. 10, 601-619 (2015). doi:10.1007/s11625-015-0333-5

64. Heemskerk, W., Wennink, B.: Building social capital for agricultural innovation: experiences with farmer groups in Sub-Saharan Africa. Bulletin of the Royal Tropical Institute, Amsterdam, vol. Bulletin 3, 120p (2004)

65. Sanginga, P.C., Lilja, N.K., Tumwine, J.: Assessing the quality of participation in farmers' research groups in the highlands of Southwestern Uganda, Kabale (2001)

66. Thomas, E., Zumr, Z., Barstow, C., Linden, K.: Proving sustainability: the international development monitoring initative. In: Proceedings of the 2011 IEEE global humanitarian technology conference GHTC, pp. 164-170. Seattle (2011). doi:10.1109/ GHTC.2011.74

67. Adida, C.L., Ferree, K.E., Posner, D.N., Robinson, A.L.: Who's asking? Interviewer coethnicity effects in African survey data. Comp. Polit. Stud. (2016). doi:10.1177/0010414016633487 